\title{
ENVIRONMENTAL ISOTOPES AND NOBLE GAS AGES OF THE DEEP GROUNDWATER WITH COUPLED FLOW MODELLING IN THE BALTIC ARTESIAN BASIN
}

\author{
R. Mokrik, V. Samalavičius, M. Gregorauskas, and M. Bujanauskas \\ Institute of Geosciences at Vilnius University, Čiurlionio 21/27, 03101 Vilnius, Lithuania \\ Email: robert.mokrik@gf.vu.lt; vytautas.samalavicius@chgf.vu.lt
}

Received 28 August 2020; revised 6 January 2021; accepted 12 January 2021

\begin{abstract}
In this study, modelled groundwater actual flow times in intermediate and deep aquifers, covered by regional scale impermeable aquitards, were compared with ${ }^{4} \mathrm{He}$ and ${ }^{81} \mathrm{Kr}$ age dating results. To improve the reliability of the steady state 3D groundwater flow model, the isotopic ages of deep groundwater were compared to the MODPATH modelled travel times. The highest helium values in groundwater reservoirs coincide with fault zones in the crystalline basement and sedimentary cover near Rapakivi granite massifs. Insights into isotope-geochemical anomalies of the Baltic Artesian Basin intermediate and deep groundwater support their main distribution peculiarities in the flow path towards the Baltic Sea coast lowland and seabed depression as the regional groundwater discharge area.
\end{abstract}

Keywords: deep groundwater dating, isotope-geochemistry, flow modelling

PACS: 91.67.Qr, 91.67.Rx, 92.40.Kf

\section{Introduction}

A new approach of deep aquifer investigation in the Baltic Artesian Basin (BAB) was focused on using a wide complex of environmental isotopes, noble gases, groundwater chemistry, and hydraulic data via coupled analysis of groundwater flow numerical models. The main aim was to analyse crustal fracturing and hydraulic migration properties of sedimentary cover related to the fault systems and aquifer reservoir role in noble gas and fluid distribution. In this study the modelled particle travel time in intermediate and deep aquifers, which are covered by thick impermeable aquitards, was compared with ${ }^{4} \mathrm{He}$ and ${ }^{81} \mathrm{Kr}$ dating results. To improve the reliability of $3 \mathrm{D}$ groundwater flow model verification, the isotopic ages of deep groundwater were compared to the MODPATH particle tracking modelled times.
In 2016-2019 Vilnius University participated in the IAEA Research Program F33022. Following this project work plan, additional 6 Lithuanian intermediate-deep boreholes with their depth varying from 300 up to $1011 \mathrm{~m}$ were studied. Stable isotopes were analysed at the Institute of Geology, Tallinn University of Technology, Estonia. In 2016-2019, at the Institute of Geosciences of Vilnius University, numerical 3D steady-state and transient groundwater models of the $\mathrm{BAB}$ were created and calibrated with groundwater head and hydraulic parameter data of wells. The modelled area is approximately $500000 \mathrm{~km}^{2}$, grid size $5 \times 5 \mathrm{~km}$, total cell number 614823 , and has 31 separated layers from the crystalline basement aquifer up to the Quaternary aquifer system. In 2013-2017, radiokrypton age was estimated for the $\mathrm{BAB}$ by cooperation of the international team for samples of seven boreholes of deep 
groundwater using the atom trap trace analysis (ATTA) method [1].

\section{Hydrogeologic framework of the Baltic Artesian Basin}

The $\mathrm{BAB}$ is a multistoried geological structure of aquifers and aquitards (Fig. 11). In western and northern marginal parts, it is inundated by the Baltic Sea that is one of the main groundwater discharge areas. The vertical sequence of groundwater bodies forms three hydrogeological units or zones - active, delayed and stagnant, separated by regional scale aquitards and formed boundary conditions for flow direction during the geotectonic development of the sedimentary basin. This separation strongly determines the isotope-geochemical composition of groundwater. Geodynamic loading processes, hydrogeochemical interactions between groundwater and rocks, groundwater flow features from the meteoric recharge area to the discharge area, and partitioning processes of isotopic composition have affected the evolution of stable oxygen-18 isotope ratio values and its localization sites inside of these zones. The zone of an active water exchange extends from the inland meteoric water recharge area to the coastal submarine discharge area which is separated in the nearshore with a transitional zone, where the inversion of groundwater heads takes place. In the inland part, meteoric water infiltration predominates downwards up to depths of 400 to $450 \mathrm{~m}$. Here the fresh carbonate type groundwater reaches a total dissolved solids (TDS) value up to $2-4 \mathrm{~g} / \mathrm{L}$. The zone of delayed groundwater is located at depths from 0.5 up to $1.5 \mathrm{~km}$. The carbonate-chloride and sulfate type groundwater of this zone varies in TDS from 5 to $60-100 \mathrm{~g} / \mathrm{L}$. Below the $1.8 \mathrm{~km}$ depth, stagnant chloride type groundwater with more than $100 \mathrm{~g} / \mathrm{L}$ in TDS is formed. Thus, the three main zones according to $\delta^{18} \mathrm{O}$ values distribution in the abovementioned groundwater zones were distinguished in the BAB.

In the active zone near surface, dominant $\delta^{18} \mathrm{O}$ values are from -8.2 up to $-11.6 \%$ o that are related to the modern meteoric water recharge and by features of lateral partitioning of the $\delta^{18} \mathrm{O}$ isotope ratio of precipitation across the region [5]. Zones with more positive $\delta^{18} \mathrm{O}$ values (from -8.2 to $-10.5 \%$ ) are located mostly in the southwestern part of the Baltic Region. In Estonia, extremely depleted zones with $\delta^{18} \mathrm{O}$ values from -14 to $-22.5 \%$ are observed reflecting palaeorecharge during the cold climate Pleistocene time. These differences in $\delta^{18} \mathrm{O}$ of groundwater are due to changes in global paleoclimatic conditions and their impact on the groundwater formation during the Pleistocene and Holocene [6]. The $\delta^{18} \mathrm{O}$ values of groundwater in most aquifers in North Poland, Kaliningrad District of Russia, Lithuania and Latvia territory range from -7.7 to $-13.9 \%$ [6, 月]. However, in the Island of Gotland (Sweden Homocline) at the same depth groundwater has significantly higher $\delta^{18} \mathrm{O}$ values ranging from -5.7 to $-6.1 \%$ [ [8].

The delayed zone is located in the western part of BAB where the TDS of groundwater gradually rises from 5-7 up to $90-100 \mathrm{~g} / \mathrm{L}$. Under the impact (a)

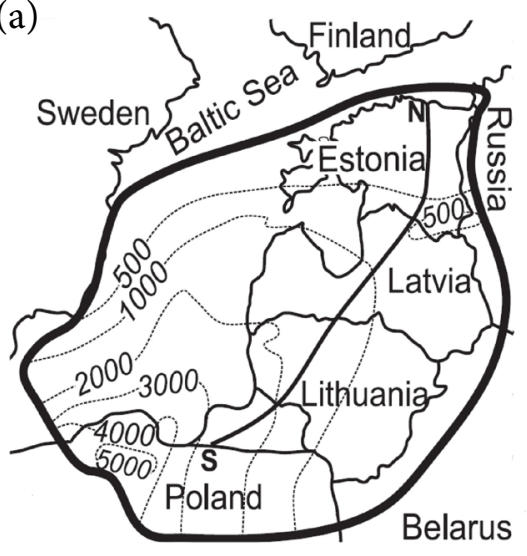

(b)

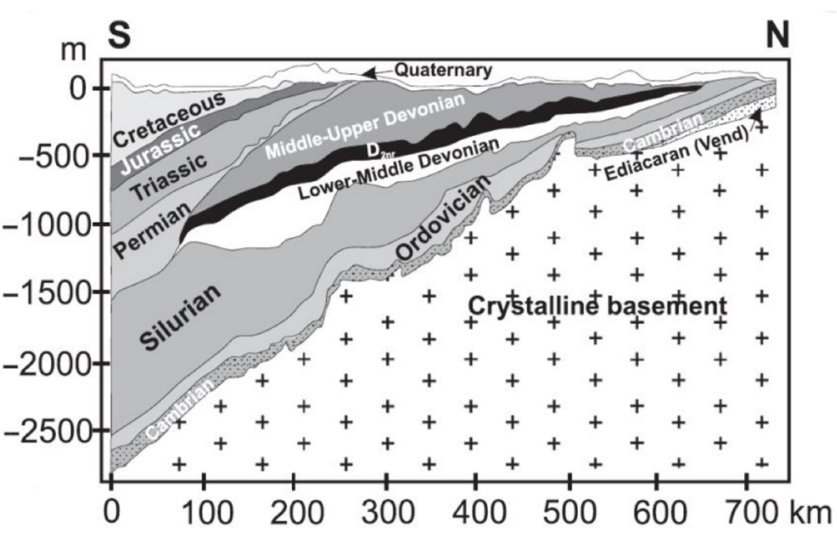

Fig. 1. (a) Location of the Baltic Artesian Basin, dotted lines represent the depth of the crystalline basement in metres below the sea level. (b) Longitudinal cross-section of the BAB [2-4]. 
of lithostatic load and tectonic activities, the compaction flow of this zone is moving toward the periphery part of the artesian basin. This zone includes three hydrogeochemical facies of groundwater: bicarbonate chloride calcium sodium, chloride magnesium sodium (marine) and chloride sodium. The average isotopic ratio $\delta^{18} \mathrm{O}$ values are -6 to $-9 \%$. In this zone, the $\delta^{18} \mathrm{O}$ values are formed like transitional media between the motion of shallow active and deep stagnant groundwater and mixing adaption.

Stagnant zone brines are under a closed system thermodynamically in complete equilibrium with sedimentary rocks of the artesian basin. Their salinity increases up to $140-300 \mathrm{~g} / \mathrm{L}$ and the value of $\delta^{18} \mathrm{O}$ is enriched ( -3 to $\left.-4.5 \%\right)$. The temperature at the top of Cambrian-Ordovician rocks varies from $98^{\circ} \mathrm{C}$ in the southwestern Lithuania coast area to $21^{\circ} \mathrm{C}$ at the Jelgava site located close to Riga city. The geothermal anomaly promotes the processes of ultrafiltration, dehydration and ion-exchange because of enrichment of deep groundwater with calcium ions, i.e. the water of chloride calcium facies is formed.

Thus, three main zones according to $\delta^{18} \mathrm{O}$ distribution in groundwater can be distinguished: 1) a near subsurface zone with $\delta^{18} \mathrm{O}$ average values from -10.0 to $-11.6 \%$ (close to local meteoric water), that are related to the modern meteoric water percolation on watersheds of highlands (eastern part of the Baltic Region); 2) zones up to $150-250 \mathrm{~m}$ depth with $\delta^{18} \mathrm{O}$ values from -10.5 to $-12.5 \%$ (more negative values than modern meteogenous water); 3 ) a zone with more enriched values $\delta^{18} \mathrm{O}>-7 \%$ o (more positive values than modern and Late Pleistocene time meteogenous water). The differences in $\delta^{18} \mathrm{O}$ of groundwater reflect changes in paleoclimatic conditions and their impact on the groundwater formation from the Early Pleistocene to Holocene.

\section{Dating methods}

During the sampling for radiokrypton dating, groundwater is being transferred through the degassing device, extracted gas is collected in a steel container [1, 9]. The krypton from bulk gas was separated and analysed with the noble gas mass spectrometric system at the University of Bern and the ${ }^{81} \mathrm{Kr} / \mathrm{Kr}$ isotope ratio was determined by using the ATTA-3 instrument in the Laboratory for Radiokrypton Dating, Argonne National Laboratory [1].

It is noteworthy that using the ${ }^{81} \mathrm{Kr} / \mathrm{Kr}$ isotope ratio for the groundwater age estimation for the $\mathrm{BAB}$ is possible only up to the lowest part of the intermedium zone at $1 \mathrm{~km}$ depth because the downward radiokrypton isotope does not have fixed tracks. So, for the deepest BAB segments, we could only use ${ }^{4} \mathrm{He}$ based age evaluation methods.

Helium in samples was analysed in the Isotope Hydrology Laboratory of the International Atomic Energy Agency (IAEA) using the methods described by Refs. [10] and [11]. A mass spectrometer MM5400 and two quadrupole mass spectrometers (QMS) along with a sample extraction system were used to determine helium quantities in groundwater sampled during the 2017 campaign. For the IAEA equipment helium was collected in copper tubes through which a constant flow of groundwater was ensured. Through clamping both ends of the copper tube, the groundwater sample is being taken without any contact with air [12].

The helium gas concentration of boreholes was analysed also using an INGEM-1 device at Vilnius University. The INGEM-1 analyzer measurement is based on the helium gas diffusion and absorption process through the quartz membrane induced by titanium cathode in the high voltage electric discharge in the magnetic field [13]. Groundwater samples from the boreholes were collected into $0.33 \mathrm{~L}$ glass bottles. The sample bottles were sealed with rubber corks. To remove air bubbles during the sample sealing a thin metal thread was used by removing it out of the bottle while the cork was pushed finally in.

For the ${ }^{4} \mathrm{He}$ age calculation (Eq. (1)), the average uranium (440 ppm) and thorium (1500 ppm) content in the crystalline basement at the northern part of the BAB was used [14]. The correction (Eq. (2)) for the helium production to the calculation of accumulation rate [15] was made using the average rock density $\left(2.5 \mathrm{~g} / \mathrm{cm}^{3}\right)$, the void ratio calculated for the porosity of reservoir aquifers $(n=0.15)$ and release factor $\Lambda_{\mathrm{He}}=1$, corrected in the fluid phase helium accumulation rate $J$ and helium production $J^{\prime}$ from the rock rate. Helium age (a) is the ratio of helium content in aquifer groundwater $\left(\mathrm{cm}^{3} \mathrm{STP} / \mathrm{g}\right)$ and corrected helium production rate $J\left(\mathrm{~cm}^{3} \mathrm{STP} /\right.$ $(\mathrm{g} \times \mathrm{a}))$ [15]: 


$$
\begin{aligned}
& J^{\prime}=0.2355 \times 10^{-12} \times[\mathrm{U}]\left(1+0.123\left(\frac{\mathrm{Th}}{\mathrm{U}}-4\right)\right), \\
& J=J^{\prime} \times \rho \times \Lambda_{\mathrm{He}} \times\left(\frac{1-n}{n}\right) .
\end{aligned}
$$

\section{Application of noble gas, stable isotopes and coupled flow modelling methods for intermediate and deep groundwater age estimation}

Deep and intermediate aquifer investigation of the $\mathrm{BAB}$ was carried out using a wide complex of environmental isotopes, noble gases, groundwater chemistry and hydraulic data via coupled analysis of groundwater flow numerical models. Helium distribution peculiarities in the $\mathrm{BAB}$ were studied for 40 years [16, 17]. Regional hydraulic ages were assessed by using particle tracking from the well sites up to the recharge area endpoints (Table 1, Fig. 2). In the case of a few flow paths crossing in the site, two most significant recharge areas were picked: Riga Well No. 50194 and Likènai, Aukštaitija Well No. 21965. Thus, two particle track ages were obtained (Table 1). The average value of both hydraulic ages is presented in the diagram of dating method comparison (Fig. 3). The deep groundwater seepage velocity estimated by particle tracking for the $\mathrm{BAB}$ for intermediate depth up to $500 \mathrm{me}-$ tres is $5 \mathrm{E}^{-3} \mathrm{~m} / \mathrm{a}$ and for $1 \mathrm{~km}$ depth it is $\sim 8 \mathrm{E}^{-4} \mathrm{~m} / \mathrm{a}$.
These results are significantly lower than modelled by the BAB steady state condition with Darcy hydraulic conductivity of $\sim 1 \mathrm{~m} / \mathrm{a}$ [3]. The modelled particle travel time in the aquifers confined with regional scale aquitards was compared with the ${ }^{4} \mathrm{He}$ and ${ }^{81} \mathrm{Kr}$ dating results. The groundwater reservoirs where elevated ${ }^{4} \mathrm{He}$ values were observed coincide with the steep fault blocks that transect the basin sedimentary cover.

The radiokrypton age was estimated in deep and intermediate $\mathrm{BAB}$ aquifer groundwater samples collected from seven boreholes in 2013-2017 [1]. The Lithuanian groundwater sampling took place during the campaigns in 2013 collecting noble gas for radiokrypton analysis in 3 boreholes: Ignalina, Klaipèda and Genčiai with cooperation from the Tallinn University of Technology and the Bern University. Helium was not measured in the Genčiai site sample. During the 2017 campaign helium and other noble gas were collected from 7 wells in Lithuania (in cooperation with IAEA). The results of Birštonas and Telšiai sites are not included in this study. The helium content data of Riga, Häädemeeste and Värska were previously published [1].

Additionally, the dissolved ${ }^{4} \mathrm{He}$ concentration data were obtained during previous fieldwork sampling and from publications [1, 16, 17].

The cross-section of the $\mathrm{BAB}$ multilayered aquifers system is a setting of the regional aquitard-aquifer framework. The regional scale impermeable

Table 1. Ages of intermediate and deep BAB aquifers groundwater determined using ${ }^{4} \mathrm{He},{ }^{81} \mathrm{Kr}$ and particle track modelling.

\begin{tabular}{ccc|c|c|c|c|c}
\hline $\begin{array}{c}\text { Well } \\
\text { No. }\end{array}$ & Site & System & Depth, $\mathrm{m}$ & $\begin{array}{c}\text { Particle travel time (modelled), } \\
\text { ka recharge from south/east }\end{array}$ & $\begin{array}{c}{ }^{4} \mathrm{He} \text { age, } \\
\text { ka }\end{array}$ & $\begin{array}{c}{ }^{81} \text { Kr age, } \\
\text { ka }\end{array}$ \\
\hline 12350 & Anykščiai & $\mathrm{D}_{1-2}$ & 360 & 70 & 76 & - \\
\hline 47543 & Palanga & $\mathrm{D}_{2}$ & 522 & 250 & 225 & - \\
\hline 12349 & Rokiškis (Vaiva) & $\mathrm{D}_{1-2}$ & 440 & 100 & 31 & - \\
\hline 21965 & Likenai (Aukštaitija) & $\mathrm{O}-\mathrm{Cm}$ & 1011 & $900 / 180$ & 308 & - \\
\hline 11978 & Likènai (Likènai) & $\mathrm{D}_{1-2}$ & 434 & 180 & 55 & - \\
\hline 50423 & Ignalina & $\mathrm{O}-\mathrm{Cm}$ & 500 & 100 & 129 & 320 \\
\hline 25872 & Klaipėda, Geoterma & $\mathrm{D}_{1-2}$ & 1100 & 400 & 597 & 1.157 \\
\hline 50194 & Riga, Hospital & $\mathrm{O}-\mathrm{Cm}$ & 1027 & $1.100 / 300$ & 326 & 929 \\
\hline 8021 & Häädemeeste & $\mathrm{O}-\mathrm{Cm}$ & 610 & 500 & 150 & 408 \\
\hline 4613 & Värska & $\mathrm{O}-\mathrm{Cm}$ & 460 & 360 & 81 & 550 \\
\hline
\end{tabular}

Note. D is Devonian, O-Cm is Ordovician-Cambrian. 


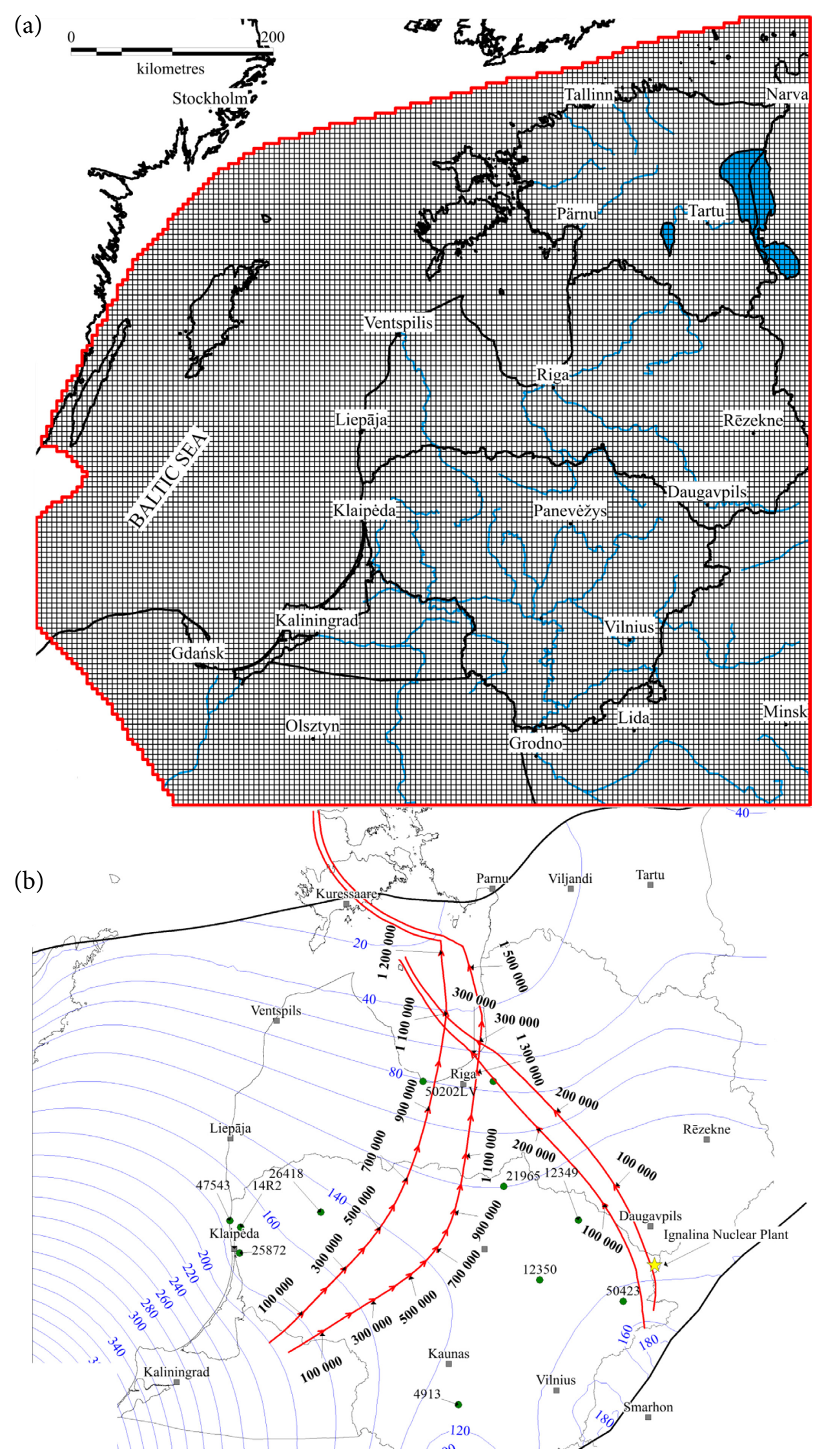

Fig. 2. (a) Numerical 3D steady-state and transient groundwater model grid of the BAB. (b) Illustration of the MODPATH modelled particle tracks for the Ordovician-Cambrian $(\mathrm{O}-\mathrm{Cm})$ aquifer. Particles were released in two recharge areas: Eastern Lithuania and the northern part of Kaliningrad District. Lines and numbers represent hydraulic head in metres above the sea level. Arrows represent the particle track and time in years, respectively. 


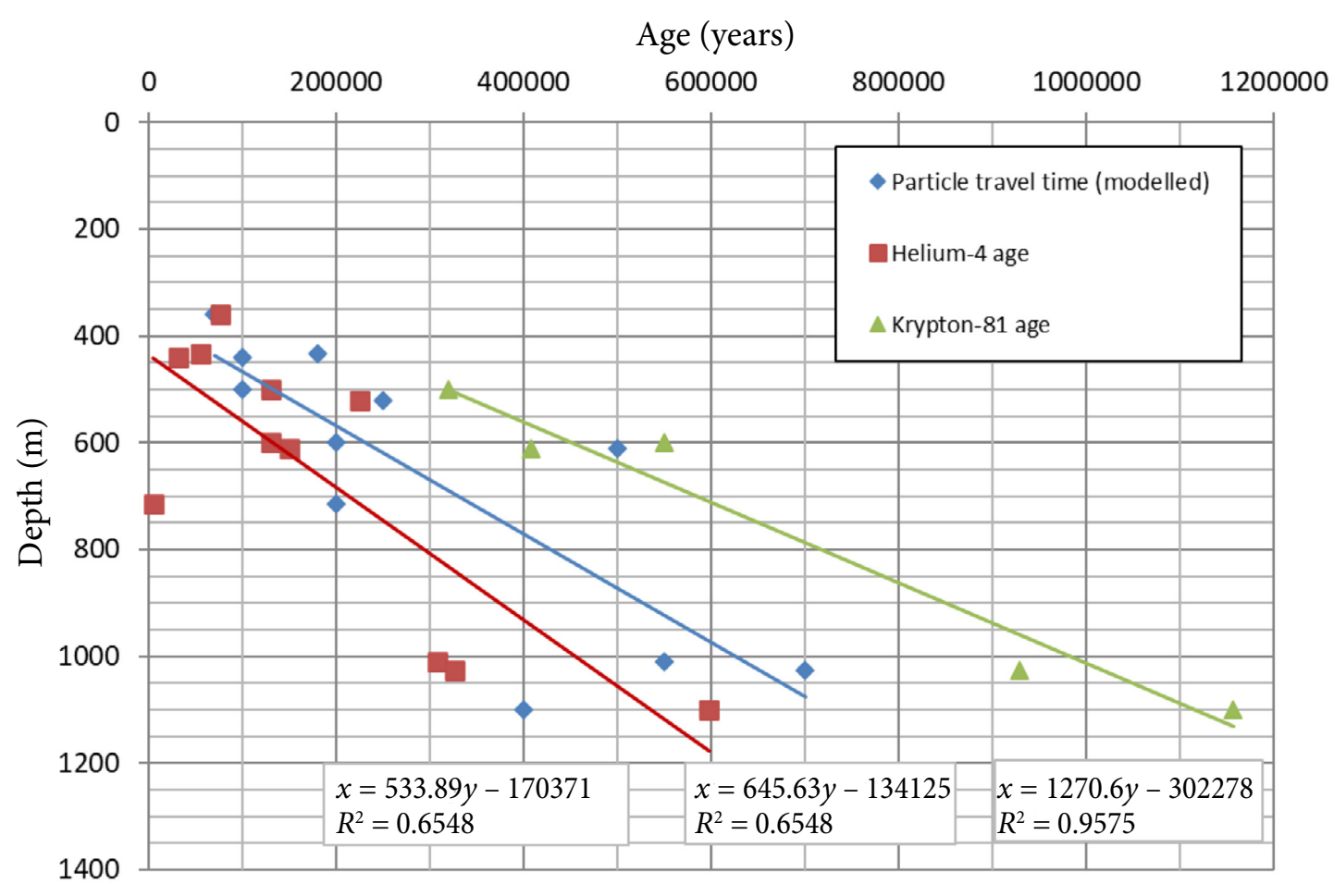

Fig. 3. Age distribution of intermediate and deep $B A B$ aquifers groundwater in depth. Age vs depth trendlines are plotted for ${ }^{4} \mathrm{He},{ }^{81} \mathrm{Kr}$ and particle travel time dating results.

aquitard acts as the main separation boundary for helium migration in deep and intermediate flows. Helium produced and emitted by basement rock and aquifer matrix migrates in vertical and lateral directions toward the surface and periphery of the basin. According to these trajectories, helium accumulation in the traps results in a cumulative scheme like apparent aggregation. The traditional binary mixing model could be used for the two aquifer units separated by regional scale impermeable aquitard calculation. A leakage from beneath is not significant because permeability of the regional scale aquitard is low. The helium anomalies are influenced by its reservoir's external/internal sources and require correction.

Difficulties of such estimation of helium content are related to the optimization of leakage parameters and the estimation of release rates of rock radiogenic alpha particles in situ. According to our preliminary assessment based on the $\mathrm{BAB}$ numerical flow model, for the interface condition between the deep/intermediate zone end-members $f_{1}, f_{2}$ values may vary in intervals of 0.15 and 0.85 , and for the intermediate/shallow interface zone in intervals of 0.33 and 0.66 , respectively. There $f_{1}$ is the helium upwelling inflow part through aquitard and $\mathrm{f}_{2}=\left(1-\mathrm{f}_{1}\right)$ is the in situ accumulation/depletion rate part. This analysis requires more detailed modelling with data in the vicinities of faults.

For the ${ }^{4} \mathrm{He}$ age estimation by Eqs. (1) and (2) many difficulties are often related to lambda factor use because a multilayered aquifer system in many cases dramatically changes the effective porosity in regard to double porosities with fracturing and diffusion coefficients of rocks.

$\delta^{2} \mathrm{H}$ and $\delta^{18} \mathrm{O}$ stable isotopes were measured in the Laboratory of Mass Spectrometry at the Department of Geology, Tallinn University of Technology. Major and trace element analyses were performed in Lithuanian and Estonian accredited laboratories.

A selective database was compiled from the data collected during the research of the $\mathrm{BAB}$ and previous studies. Criteria for data selection were to pick samples that are exclusive in the context of other $\mathrm{BAB}$ groundwater. In the case of intermediate and deep aquifers, additional criteria for groundwater dating results $\left({ }^{4} \mathrm{He},{ }^{81} \mathrm{Kr}\right.$, or particle travel time) were necessary. All data were divided into groups considering groundwater depth (modern-shallow, intermediate, deep), location, and structural features of the crystalline basement. Saturation indices for calcite, gypsum and halite were modelled 
using the software Phreeqc, wateq4 database. In case the data was not available, the initial conditions were applied: temperature $10^{\circ} \mathrm{C}$, electron activity (pe) 0 , density $1 \mathrm{~g} / \mathrm{mL}$. All stable oxygen and deuterium isotope data are expressed in the Vienna Standard Mean Ocean Water (VSMOW) system.

\subsection{Dating results of intermediate and deep aquifers}

Radiokrypton is meteoric in origin and has the same downward-lateral flow trajectory as a modelled particle track. This statement is applicable for the multilayered aquifer systems and confined aquifer isolated from above by local aquitards where a shallow and intermediate groundwater flow direction up to $0.5-1 \mathrm{~km}$ depth is predominantly lateral from the recharge area toward local discharge places on land and regional discharge sites on the Baltic Sea lowland and offshore. The BAB hydraulic conductivity values of such aquitards, which confine aquifers from meteoric water leakage on a regional scale, are below $5 \mathrm{E}^{-7} \mathrm{~m} / \mathrm{d}$ [6]. Here the main source of emanation of ${ }^{4} \mathrm{He}$ occurs due to the decay of uranium and thorium in minerals of the crystalline basement rock. Helium diffuses through fractures and tectonic faults to sedimentary reservoirs where it accumulates. Cases, where vertical local uplift blocks confine groundwater aquifers (offset from 100 to $600 \mathrm{~m}$ ), could prevent lateral migration of fluid. At that boundary as such on the contact with the regional impermeable aquitard, the accumulation rate of crustal origin noble gases has increased significantly. The helium amount in the deep and at the lower part of intermediate groundwater of the $\mathrm{BAB}$ vary, respectively: $4.6 \mathrm{E}^{-8}$ up to $9.0 \mathrm{E}^{-4} \mathrm{~cm}^{3}$ $\mathrm{STP} / \mathrm{g}$ [6]. High helium accumulation rate in groundwater is observed in the periphery margin of the Estonian Homocline and Belarus-Mazurian Massif, Polish-Lithuanian Trough, Liepaja-RigaPskov Ridge, and with Baltic Sea Depression related Rapakivi granite massifs in the basement [6]. The mentioned tectonic structures are bounded by Paldisk-Pskov, Middle Estonian, Liepaja-Saldus-Riga and West Lithuanian fault zones. These fault zones separate regions where groundwater movement rates are relatively fast from stagnant in the deepest parts of the BAB. The average velocity in the peripheral part up to the intermediate depth of the $\mathrm{BAB}$ varies from 0.2 to $1 \mathrm{~m} / \mathrm{a}$.
The helium age calculation shows that older groundwater may originate in an intermediate depth aquifer compared to that located deeper (Tables 2, 3). It contradicts groundwater chemical composition and dating results obtained using other techniques, therefore should be considered

Table 2. Apparent aggregate ${ }^{4} \mathrm{He}$ content and age in the Klaipeda site of multilayered aquifer systems [1, $6,16,17]$.

\begin{tabular}{|c|c|c|}
\hline System & $\mathrm{He}, \mathrm{cm}^{3} \mathrm{STP} / \mathrm{g}$ & Age, ka \\
\hline $\mathrm{T}$ & Aquitard & - \\
\hline $\mathrm{P}_{2}$ & $4.56 \mathrm{E}^{-8}$ & Modern by ${ }^{14} \mathrm{C}$ data \\
\hline $\mathrm{D}_{3}$ & Low helium content & Modern by ${ }^{14} \mathrm{C}$ data \\
\hline $\mathrm{D}_{2-3}$ & Aquitard & - \\
\hline $\mathrm{D}_{2}$ & $3.06 \mathrm{E}^{-4}$ & 225 \\
\hline $\mathrm{D}_{2}$ & $\begin{array}{c}\text { Regional scale } \\
\text { intermediate depth } \\
\text { aquitard }\end{array}$ & - \\
\hline $\mathrm{D}_{1-2}$ & $8.12 \mathrm{E}^{-4}$ & 597 \\
\hline$S$ & $\begin{array}{c}\text { Regional scale deep } \\
\text { aquitard }\end{array}$ & - \\
\hline $\mathrm{O}-\mathrm{Cm}$ & $9.00 \mathrm{E}^{-4}$ & 662 \\
\hline$\Sigma$ & $\begin{array}{c}\text { Total aggregated } \\
2.0 \mathrm{E}^{-3}\end{array}$ & \\
\hline
\end{tabular}

Note. T is Triassic, P is Permian, D is Devonian, S is Silurian, $\mathrm{O}-\mathrm{Cm}$ is Ordovician-Cambrian.

Table 3. Apparent aggregate ${ }^{4} \mathrm{He}$ content and age in the Värska site of multilayered aquifer systems $[1,6$, $16,17]$.

\begin{tabular}{ccc}
\hline System & $\mathrm{He}, \mathrm{cm}^{3} \mathrm{STP} / \mathrm{g}$ & Age, ka \\
\hline $\mathrm{D}_{2}$ & Aquitard & - \\
\hline $\mathrm{D}_{1-2}$ & $4.75 \mathrm{E}^{-5}$ & 35 \\
\hline $\mathrm{S}-\mathrm{O}$ & Aquitard & - \\
\hline $\mathrm{O}-\mathrm{Cm}$ & $1.10 \mathrm{E}^{-4}$ & 81 \\
\hline $\mathrm{Cmln}$ & $\begin{array}{c}\text { Intermediate depth regional } \\
\text { scale aquitard }\end{array}$ & - \\
\hline $\mathrm{V}_{2} \mathrm{vr}$ & $1.17 \mathrm{E}^{-4}$ & 86 \\
\hline $\mathrm{V}_{2} \mathrm{kt}$ & Aquitard & - \\
\hline $\mathrm{V}_{2} \mathrm{gd}$ & $3.09 \mathrm{E}^{-6}$ & 2 \\
\hline$\Sigma$ & Total aggregated $2.78 \mathrm{E}^{-4}$ \\
\hline
\end{tabular}

Note. D is Devonian, S-O is Silurian-Ordovician, O-Cm is Ordovician-Cambrian, Cmln is Cambrian Lontova, $\mathrm{V}_{2} \mathrm{vr}$ is Vendian Voronka, $\mathrm{V}_{2} \mathrm{kt}$ is Vendian Kotlin, $\mathrm{V}_{2} \mathrm{gd}$ is Vendian Gdov. 
while interpreting helium ages. Apparent aggregated helium age in the multilayered aquifer matrix unit is the sum of all groundwater helium rates released from sources in a particular site (Tables 2, 3). During the Pleistocene period, very specific migration conditions through the sedimentary cover existed. Permafrost screening conditions, ice loading, etc. drastically changed the flow path. One of the problems is that helium bulk loss from reservoirs is practically unproved. These circumstances plausibly formed many replacements for helium anomalies and in general established a highly elevated content of helium gas in the Baltic Sea shore vicinity.

Interesting results of the $\mathrm{U}-\mathrm{He}$ relationship to identify the ${ }^{4} \mathrm{He}$ source within the Canadian Quebec Region reveal that glaciation time fracturing of periglacial aquifers induced high helium release rates [18]. The coupled model between the activity of ${ }^{234} \mathrm{U} /{ }^{238} \mathrm{U}$ isotope ratio, fractionation and radiogenic helium excesses was developed. It suggests a process within the aquifer to explain the ${ }^{4} \mathrm{He}$ excesses, providing a complementary approach to the hypothesis of external sources of helium. According to the authors, the $\mathrm{U}-\mathrm{He}$ relationship analysis suggests a common enhanced radiogenic ${ }^{4} \mathrm{He}$ release process in groundwater by ${ }^{234} \mathrm{U} \alpha$-recoil and helium diffusion: these release rates are between 1000 and 30,000 times higher than the local $\mathrm{U}$ and Th steady state production rate. Simulated ${ }^{234} \mathrm{U} /{ }^{238} \mathrm{U}$ activity ratio evolution as a function of groundwater residence time, based on the meas- ured for the ratio maximum value, was calibrated by the ${ }^{14} \mathrm{C}$ adjusted age $6.7 \mathrm{ka}[18]$. In the northwestern part of $\mathrm{BAB}$, the Cambrian-Vendian aquifer, which is close to Rapakivi granite massifs, the groundwater at the interface boundary with the basement groundwater ${ }^{234} \mathrm{U} /{ }^{238} \mathrm{U}$ activity ratio varies from 3 to 26 [19]. The groundwater of $\mathrm{Cl}-\mathrm{HCO}_{3}-\mathrm{Ca}-\mathrm{Na}$ type has increased the TDS content, mostly $0.8-1.2 \mathrm{~g} / \mathrm{L}$, and the permafrost model for that formation was build up [6, 20]. Applying [18] the simulation build up trend-line for residence time, the Cambrian-Vendian groundwater age by the ${ }^{234} \mathrm{U} /{ }^{238} \mathrm{U}$ activity ratio may be evaluated as $30-80 \mathrm{ka}$. It is noteworthy that in these groundwater facies the stable oxygen-18 isotope ratio value is strongly depleted $\left(\delta^{18} \mathrm{O}\right.$ from -20 to $-22.5 \%$ ) with a low ${ }^{14} \mathrm{C}$ content [8].

Two cases of helium distribution and apparent aggregate helium age are presented in this study. The distribution of helium content $\left(\mathrm{cm}^{3} \mathrm{STP} / \mathrm{g}\right)$ in the Klaipeda-Palanga site aquifers is the following: $\mathrm{O}-\mathrm{Cm} 9.0 \mathrm{E}^{-4}, \mathrm{D}_{1-2} 8.1 \mathrm{E}^{-4}, \mathrm{D}_{2} 3.1 \mathrm{E}^{-4}, \mathrm{P}_{2} 4.6 \mathrm{E}^{-8}$. The sum of helium content in the Klaipeda site is $20.2 \mathrm{E}^{-4} \mathrm{~cm}^{3} \mathrm{STP} / \mathrm{g}$ (Table 2). The value of aggregate helium age could suggest more reliable dating of the deepest aquifer which in this case is $\mathrm{O}-\mathrm{Cm}$. Perhaps the real groundwater age is more likely about $1.5 \mathrm{Ma}$ for this aquifer system than $0.66 \mathrm{Ma}$ (by conventional helium dating for lower aquifer) considering that radiokrypton measured in the overlaying $\mathrm{D}_{1-2}$ aquifer dates groundwater up to $1.2 \mathrm{Ma}$.

Table 4. Isotope-geochemistry data of intermediate and deep BAB aquifers groundwater (2013-2017 campaign sampling).

\begin{tabular}{|c|c|c|c|c|c|c|c|c|c|c|c|c|c|c|}
\hline $\begin{array}{l}\text { Well } \\
\text { No. }\end{array}$ & $\mathrm{pH}$ & $\begin{array}{l}\text { Eh, } \\
\mathrm{mV}\end{array}$ & $\begin{array}{c}\delta^{18} \mathrm{O} \\
\% 0\end{array}$ & $\begin{array}{c}\delta^{2} \mathrm{H}, \\
\% о\end{array}$ & $\begin{array}{c}\mathrm{Cl}^{-}, \\
\mathrm{mg} / \mathrm{L}\end{array}$ & $\begin{array}{l}\mathrm{SO}_{4}^{2-} \\
\mathrm{mg} / \mathrm{L}\end{array}$ & $\begin{array}{c}\mathrm{HCO}_{3}^{-}, \\
\mathrm{mg} / \mathrm{L}\end{array}$ & $\begin{array}{l}\mathrm{Na}^{+}, \\
\mathrm{mg} / \mathrm{L}\end{array}$ & $\begin{array}{c}\mathrm{K}^{+}, \\
\mathrm{mg} / \mathrm{L}\end{array}$ & $\begin{array}{l}\mathrm{Mg}^{2+}, \\
\mathrm{mg} / \mathrm{L}\end{array}$ & $\begin{array}{l}\mathrm{Ca}^{2+}, \\
\mathrm{mg} / \mathrm{L}\end{array}$ & $\begin{array}{l}\text { TDS, } \\
\mathrm{mg} / \mathrm{L}\end{array}$ & $\begin{array}{c}\text { SI } \\
\text { calcite }\end{array}$ & $\begin{array}{c}\text { SI } \\
\text { halite }\end{array}$ \\
\hline 350 & .01 & & -9.63 & 2.78 & 700 & 3500 & 69 & & 99 & & & & & \\
\hline 47543 & .16 & -207 & -9.72 & 69.96 & 12100 & 2008 & 97 & 5790 & 196 & 50 & 2001 & 22772 & ? & -2.95 \\
\hline 12349 & .44 & -102 & -1139 & 6 & 1630 & 20 & 116 & 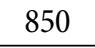 & 54 & . & 74 & 5623 & & -4.56 \\
\hline 21965 & 6.53 & -180 & -5.75 & -45.97 & 69600 & 1630 & 38 & 32450 & 308 & 2700 & 7780 & 114715 & -0.42 & -1.39 \\
\hline 11978 & 7.54 & $-1 / 2$ & -12.17 & 0.41 & 500 & 2050 & 82 & 14 & 42 & 15 & 77 & 6894 & 0 & -4.18 \\
\hline 50423 & 7.55 & -12 & -723 & -55.20 & 26348 & 2589 & 162 & 145 & 190 & 764 & 1781 & 46451 & 0.7 & -2.22 \\
\hline 25872 & 5.74 & -110 & -4.46 & -34.70 & 57470 & 1712 & 20 & 24947 & 594 & 2319 & 6787 & 94221 & & -1.64 \\
\hline 50194 & 8.1 & -71.8 & 4.79 & -42.70 & 0 & 1379 & 2 & 20 & 3 & 2 & 8 & 1142 & 0.86 & -1.37 \\
\hline 8021 & 7.52 & -38 & -13.61 & -100.7 & 93 & 73 & 271 & 16 & 36 & 78 & 175 & 5392 & 0.31 & -3.98 \\
\hline 4613 & 7.22 & -21 & -12.63 & -92.80 & 11240 & 249 & 189 & 5348 & 80 & 383 & 1006 & 18550 & 0.34 & -2.99 \\
\hline
\end{tabular}

Note. SI is saturation index. 
The case of Värska, in southern Estonia, presents an even more extreme case, where the deepest aquifer (of $\mathrm{V}_{2} \mathrm{gd}$ ) groundwater contains more than 40 times less helium than overlaying aquifers (Table 3). The helium amount in the aquifer of Värska $\left(\mathrm{cm}^{3} \mathrm{STP} / \mathrm{g}\right)$ is the following: $\mathrm{V}_{2} \mathrm{gd} 3.1 \mathrm{E}^{-6}$, $\mathrm{V}_{2} \mathrm{vr} 1.2 \mathrm{E}^{-4}, \mathrm{O}-\mathrm{Cm} 1.1 \mathrm{E}^{-4}, \mathrm{D}_{1-2} 4.8 \mathrm{E}^{-5}$. The sum of helium content in the Värska site is $2.8 \mathrm{E}^{-4} \mathrm{~cm}^{3} \mathrm{STP} / \mathrm{g}$. There the $\mathrm{O}-\mathrm{Cm}$ aquifer has an in situ source for the helium rate released from the Alum Shale Formation radiogenic rocks (Table 3). A similar estimation of the age of the deepest $\mathrm{V}_{2}$ gd aquifer groundwater could be deduced applying the aggregate helium age of $0.2 \mathrm{Ma}$. The conventional helium method dates groundwater to $0.002 \mathrm{Ma}$, almost 100 times younger. It is necessary to mention that this approach is not necessarily accurate. The radiokrypton age in the Värska $\mathrm{O}-\mathrm{Cm}$ aquifer dates groundwater up to $0.6 \mathrm{Ma}$, that is 3 times older than the aggregate helium age. The most likely reason for that is a loss of helium which escapes to the atmosphere due to insufficient aquitard confining capacity or ice period influences by depletion. In such cases the sum of accumulated helium is not equal to its total bulk emanation.

Groundwater residence times in intermediate and deep aquifers in general increase with depth (Fig. 3). The oldest groundwater age is obtained using a radiokrypton tracer. The particle tracking and ${ }^{4} \mathrm{He}$ dating results show a good correlation and are significantly younger as compared with the radiokrypton method in most sites. Linear equations of the age-depth correlation are presented in Fig. 3.

The greatest differences of groundwater dating results are at $1 \mathrm{~km}$ depth where the ${ }^{81} \mathrm{Kr}$ obtained age is more than 2 times greater compared to helium and particle tracking methods. These aquifers are well confined with the regional scale aquitard of Silurian rocks. The differences between ages could be explained by the reduced helium amount in the aquifer. It is most likely that helium escapes from deep aquifers through tectonic faults and diffuses upwards. The results of modelled particle tracking resident times are slightly higher than ${ }^{4} \mathrm{He}$ and much lower than radiokrypton. The radiokrypton and particle track paths of shallow and intermedium aquifer are moved from the Baltic Highlands on lateral flow towards discharge sites in the Baltic Sea seabed area. The modelled aq- uifers are digitized without any geological structures able to retard a flow (for example, vertical faults) which can immobilize or slow groundwater motion, therefore the radiokrypton dating shows older groundwater compared to particle track.

The particle travel time and ${ }^{4} \mathrm{He}$ age are very similar in the Lithuanian intermediate aquifers (Table 1). The intermediate depth Estonian and Latvian groundwaters show a very young ${ }^{4} \mathrm{He}$ age compared to the radiokrypton and particle travel time. Structural features of the intermediate aquifers located in the Lithuanian-Poland Trough may result in a higher accumulation of helium than on the Saldus-Riga-Pskov Ridge (Latvia) and southern Estonian High. An uneven distribution of uranium and thorium in the crystalline basement could partly explain a low helium content in eastern Latvia, Estonia and Lithuania as well, yet this hypothesis is inconclusive because an elevated content of radioactive elements is distributed sporadically in many places [14, 16, 17]. High helium values in groundwater reservoirs coincide with the crystalline basement deformation zone near Rapakivi granite massifs [6, 14, 16, 17]. Two sites in the Lower-Middle Devonian aquifer system of East Lithuania show 3 times younger ${ }^{4} \mathrm{He}$ age than the particle track: Likenai (Well No. 11978) and Rokiškis (Well No. 12349).

\subsection{Isotope-geochemistry anomalies of groundwater, their age and origin}

The groundwater of deep aquifers in Lithuania and Latvia (Fig. 4. (a)) are usually enriched with $\delta^{2} \mathrm{H}$ and $\delta^{18} \mathrm{O}$ isotopes in respect to current modern water in shallow aquifers $\left(\delta^{18} \mathrm{O}\right.$ from -11.2 to $-10.5 \%$ ). Utmost enrichment is in deep brines, where $\delta^{18} \mathrm{O}$ varies between -5.8 to -4.4 per mil (Table 4 ). A deuterium excess could be explained by the evaporation factor which took place during the brine evolution. Another hypothesis could suggest that groundwater isotope fractionation occurs through ultrafiltration through thick aquitards. The deep groundwater age is from a few hundred thousand to more than a million years old that is sufficient for a significant stable isotope fractionation due to ultrafiltration [6]. The evaporation trend and enrichment of stable isotopes are clear in Fig. 4(a). Stable isotope values of groundwater collected near the tectonic faults fall exactly between modern freshwater and brine, 
(a)

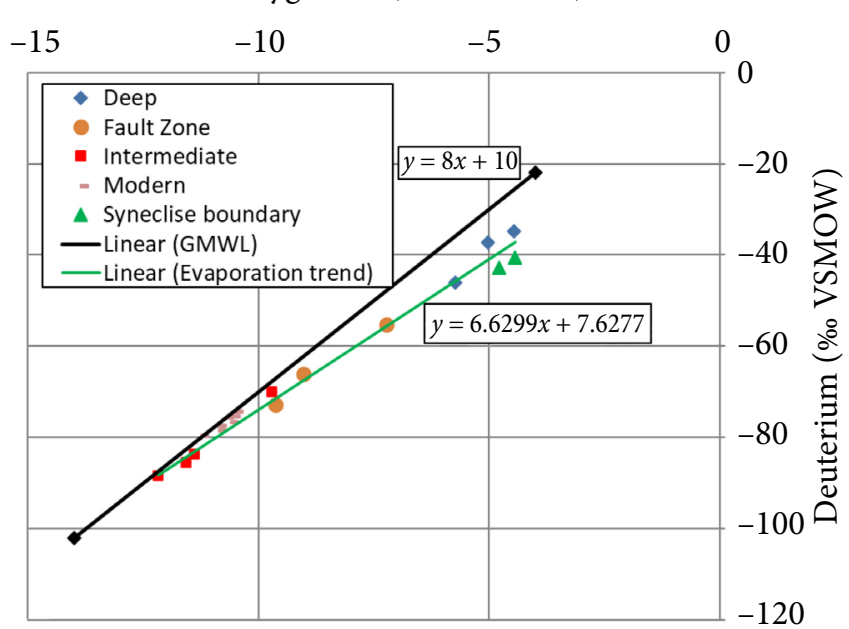

(b) Oxygen-18 (\%o VSMOW)

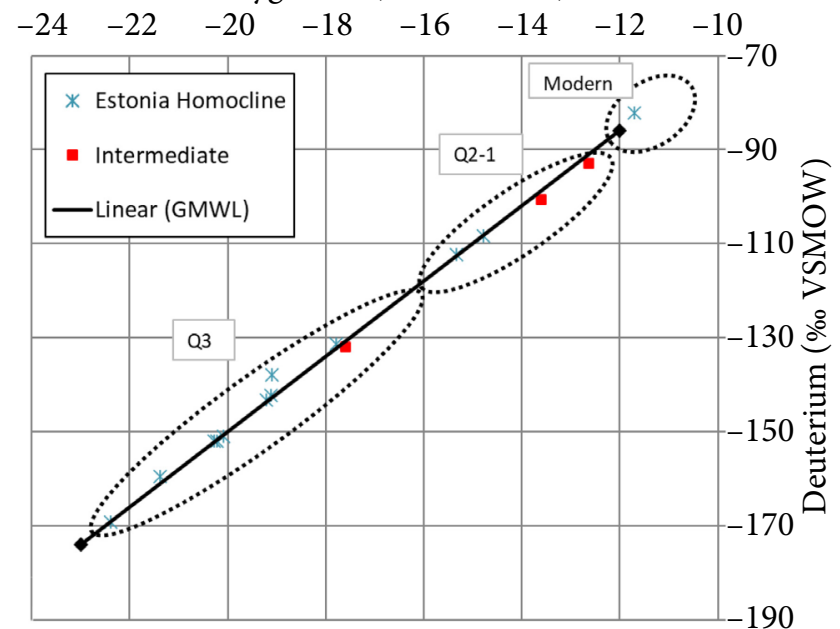

Fig. 4. (a) Craig diagram of the BAB Lithuanian and Latvian groundwater. The line represents the evaporation trend. (b) Craig diagram of the BAB Estonian groundwater. Estimated groundwater formation periods (dotted ovals): Q3, the Late Pleistocene; Q2-1, the Early-Middle Pleistocene; Modern, modern meteoric water recharge.

as they do at one intermediate aquifer site (Well No. 47543, Palanga). This supports the opinion that groundwater in these hydrogeological conditions is formed utilizing binary mixing, brine groundwater discharge into freshwater aquifers [21-26].

A few sites of intermediate aquifer groundwater located in northern Lithuania are slightly depleted with stable isotopes $\left(\delta^{18} \mathrm{O}\right.$ from -11.6 to $-12.2 \%$ ). A minor deuterium excess is observable. A few hypotheses could be forwarded to explain this phenomenon. Depletion of stable isotopes could be a result of glacial time precipitation recharge and meltwater injection or caused by permafrost induced Rayleigh distillation [27-29].

Radiocarbon dating of shallow groundwater in the northern Estonia $\mathrm{Cm}-\mathrm{V}$ aquifer system suggests formation time during the Late Pleistocene $(17$ to $33 \mathrm{ka})$ [30-32]. At sites where modern groundwater recharge takes place, groundwater is significantly younger ( 7 to $10 \mathrm{ka}$ ). Radiokrypton measured in the intermediate depth aquifer sites Värska and Häädemeeste dates groundwater 550 and $408 \mathrm{ka}$, respectively (Table 1). These ages correspond to the Middle Pleistocene. A relation between groundwater age and its stable isotope content is presented in Fig. 4(b). Three major groups are established: groundwater affected in the Late Pleistocene $\left(\delta^{18} \mathrm{O}-23\right.$ to $-17 \%$ ), the Middle (and possibly Early) Pleistocene groundwater $\left(\delta^{18} \mathrm{O}\right.$ from -17 to $\left.-12 \%\right)$ and modern recharge $\left(\delta^{18} \mathrm{O}>-12 \%\right)$. Due to the fact that most of the $\mathrm{Cm}-\mathrm{V}$ and $\mathrm{O}-\mathrm{Cm}$ groundwater date back to the Pleistocene it is safe to assume that global glaciation and climate change processes could have affected its isotope hydrochemistry. Multiple formation scenarios are suggested to explain the origin of the $\mathrm{Cm}-\mathrm{V}$ and $\mathrm{O}-\mathrm{Cm}$ groundwater isotope geochemistry: glacial time precipitation recharge and meltwater injection, seawater intrusion, modern groundwater recharge and cryogenic alteration $[6,8,19,20,33-37$.

\section{Conclusions}

A new approach of deep aquifer investigation should be focused on coupled analysis using a wide complex of environmental isotopes, noble gases, groundwater chemistry, and hydraulic data of numerical flow models.

The biggest accumulation rates of helium in the $\mathrm{BAB}$ deep aquifers are located near the Baltic Sea coast and islands. In this area, intermediate and deep groundwater flow is discharged to the Baltic Sea depression and confined from meteoric water percolation. Deep and intermediate flows are separated by regional scale aquitards and helium leakages are possible only through the faults system network in the sedimentary cover. Vertical fault block dislocations in many cases may reduce or interrupt regional groundwater 
lateral flow paths. Depending on sedimentary cover parameters and aquifer features, the radiogenic helium from the crystalline basement has good conditions to accumulate below regional scale aquitards at reservoir traps. Due to its atmospheric origin, the radiokrypton pathway should be similar to the modelled meteoric recharged particle travel trajectory in the multilayered confined aquifer system. Yet, the difference between radiokrypton ages and particle travel times is significant. The absence of fault zones in the numerical model may be substituted for the correction of hydraulic parameters in layers to reflect the natural hydrogeological internal boundary setting more accurately. Including fault zone geometry and other parameters into the numerical model is a necessary step for further analysis of the coupled radiokrypton, ${ }^{4} \mathrm{He}$, and groundwater age obtained by particle tracking.

\section{Summary}

In this study, modelled groundwater actual flow times in intermediate and deep aquifers, covered by impermeable aquitards, were compared with the ${ }^{4} \mathrm{He}$ and ${ }^{81} \mathrm{Kr}$ dating results of the Baltic Artesian Basin groundwater. The isotope-geochemistry data helped to calibrate and preliminarily verify earlier developed steady state $3 \mathrm{D}$ groundwater flow models. The elevated helium content in the aquifers coincides with deformation zones in the crystalline basement and sedimentary cover close to Rapakivi granite massifs. Atmospheric in origin, the ${ }^{81} \mathrm{Kr}$ flow path should conform to the particle travel trajectory and show similar groundwater age results. Yet, the ${ }^{81} \mathrm{Kr}$ age and particle travel times are significantly different. The numerical model lacks structural elements such as faults, therefore correction of hydraulic parameters must be made to reflect natural conditions. The formation, age and origin of the Baltic Region groundwater anomalies are supported by the environmental isotope-geochemical data.

\section{Acknowledgements}

The work has been performed in a joint effort by Research Program F33022 between Vilnius University and IAEA. The authors are grateful for the noble gas analysis to Takuya Matsumoto, Isotope Hydrologic Section, IAEA, Vienna, Austria.

\section{References}

[1] C. Gerber, R. Vaikmäe, W. Aeschbach, A. Babre, W. Jiang, M. Leuenberger, Z.T. Lu, R. Mokrik, P. Müller, V. Raidla, et al., Using ${ }^{81} \mathrm{Kr}$ and noble gases to characterize and date groundwater and brines in the Baltic Artesian Basin on the one-million-year timescale, Geochim. Cosmochim. Acta 205, 187-210 (2017), https://doi.org/10.1016/j. gca.2017.01.033

[2] V. Juodkazis, Hydrogeological Map of the Prequaternary Deposits of the Soviet Baltic Republics (Ministry of Geology of the USSR, 1980).

[3] J. Virbulis, U. Bethers, T. Saks, J. Sennikovs, and A. Timuhins, Hydrogeological model of the Baltic Artesian Basin, Hydrogeol. J. 21, 845-862 (2013), https://doi.org/10.1007/s10040-013-0970-7

[4] J. Pärn, V. Raidla, R. Vaikmäe, T. Martma, J. Ivask, R. Mokrik, and K. Erg, The recharge of glacial meltwater and its influence on the geochemical evolution of groundwater in the OrdovicianCambrian aquifer system, northern part of the Baltic Artesian Basin, Appl. Geochem. 72, 125-135 (2016), https://doi.org/10.1016/j.apgeochem.2016.07.007

[5] V. Raidla, Z. Kern, J. Pärn, A. Babre, K. Erg, J. Ivask, A. Kalvāns, B. Kohán, M. Lelgus, T. Martma, et al., A $\delta^{18} \mathrm{O}$ isoscape for the shallow groundwater in the Baltic Artesian Basin, J. Hydrol. 542, 254-267 (2016), https://doi.org/10.1016/j.jhydrol.2016.09.004

[6] R. Mokrik, The Paleohydrogeology of the Baltic Basin (Vilnius University Publishing House, Vilnius, 2003).

[7] K. Rozanski and A. Zuber, Glacial infiltration in Europe - myth or reality, Przegląd Geol. 48, 796803 (2000).

[8] R. Mokrik, The Palaeohydrogeology of the Baltic Basin. Vendian and Cambrian (Tartu University Press, 1997).

[9] Z.T. Lu, P. Schlosser, W.M. Smethie, N.C. Sturchio, T.P. Fischer, B.M. Kennedy, R. Purtschert, J.P. Severinghaus, D.K. Solomon, T. Tanhua, and R. Yokochi, Tracer applications of noble gas radionuclides in the geosciences, Earth-Sci. Rev. 138, 196-214 (2014), https://doi.org/10.1016/j. earscirev.2013.09.002 
[10]A. Suckow, M. Gröning, M. Jaklitsch, L.-H. Han, and P. Aggarwal, in: Proceedings of 4th Mini Conference on Noble Gases in the Hydrosphere and Natural Gas Reservoirs (Potsdam, 2007) pp. 115, https://doi.org/10.2312/GFZ.mga.050

[11]T. Matsumoto, D.K. Solomon, L. AraguásAraguás, and P. Aggarwal, The IAEA's coordinated research project on estimation of groundwater recharge and discharge by using the tritium, helium-3 dating technique, Geochem. J. 51, 385-390 (2017), https://doi.org/10.2343/geochemj.2.0500

[12]W. Aeschbach-Hertig, Groundwater Sampling for Helium/Noble Gases (2020), https://www.iup.uniheidelberg.de/

[13]L.E. Levina, V.V. Demanov, V.E. Stadnik, Yu.A. Galaskokov, V.V. Ermakov, N.N. Gartayenov, and I.N. Yanitskii, A measuring device for helium analysis in geological investigations, EI. VEAMS Series 10, 1-22 (1975) [in Russian].

[14]R. Raudsep, in: Geology and Mineral Resources of Estonia, eds. A. Raukas, A. Teedumäe (Estonian Academy Publishers, Tallinn, 1997) pp. 436, https://geoloogia.info/

[15]T. Torgersen and M. Stute, in: Isotope Methods for Dating Old Groundwater (International Atomic Energy Agency, Vienna, 2013) pp. 376, https:// www-pub.iaea.org/MTCD/Publications/PDF/ Pub1587_web.pdf

[16]V. Juodkazis and K. Tibar, Helium in groundwater on the northern flank of the Baltic Artesian Basin, Int. Geol. Rev. 31, 736-743(1989).

[17]R. Mokrik, V. Puura, T. Floden, and R. Petkevičius, Peculiarities of helium distribution in the Baltic Basin, Litosfera 6, 121-123 (2002).

[18]P. Mejean, D.L. Pinti, B. Ghaleb, and M. Larocque, Fracturing-induced release of radiogenic ${ }^{4} \mathrm{He}$ and ${ }^{234} \mathrm{U}$ into groundwater during the last deglaciation: An alternative source to crustal helium fluxes in periglacial aquifers, J. Am. Water Resour. Assoc. 53, 5677-5689 (2017), https://doi.org/10.1002/2016WR020014

[19] M. Yezhova, V. Polyakov, A. Tkachenko, L. Savitski, and V. Belkina, Paleowaters of North Estonia and their influence on changes of resources and quality of fresh groundwaters of large coastal water supplies, Geology 19, 37-40 (1996).
[20]R. Mokrik, Pecularities of the formation of the isotopic composition of underground waters on the southern slope of the Baltic shield, Geologija 19, 16-25 (1996).

[21]V. Juodkazis, Regional Hydrogeology of the Baltic Region (Mokslas, Vilnius, 1989) [in Russian].

[22]V. Juodkazis, Regional Hydrogeology Foundations (Vilnius University Publishing House, Vilnius, 2003) [in Lithuanian].

[23]J. Mažeika, Regularities of Radionuclide Migration and Transformation in Lithuanian Geological Environment, Habilitation Thesis (1999).

[24]A. Zuzevičius, J. Mažeika, and V. Baltrūnas, A model of brackish groundwater formation in the Nemunas River Valley, Geologija 60, 63-75 (2007).

[25]A. Zuzevičius, The groundwater dynamics in the southern part of the Baltic Artesian Basin during the Late Pleistocene, Baltica 23, 1-12 (2010).

[26]M. Gregorauskas, K. Kaušinis, M. Bujanauskas, V. Samalavičius, and R. Mokrik, Cenomanioapatinès kreidos sluoksnio požeminio vandens išteklių ir hidrocheminių anomalijų modelinis ịvertinimas, Geologija. Geografija 3, 73-79 (2017), https://doi.org/10.6001/geol-geogr.v3i2. 3538 [in Lithuanian].

[27]I. Clark and P. Fritz, Environmental Isotopes in Hydrogeology (Lewis Publishers, Boca Raton, 1997), https://doi.org/10.1201/9781482242911

[28]J.R. O'Neil, Hydrogen and oxygen isotope fractionation between ice and water, J. Phys. Chem. 72(10), 3683-3684 (1968), https://doi. org/10.1021/j100856a060

[29]M. Lehmann and U. Siegenthaler, Equilibrium oxygen- and hydrogen-isotope fractionation between ice and water, J. Glaciol. 37, 23-26 (1991), https://doi.org/10.3189/S0022143000042751

[30]J. Banys, V. Juodkazis, and R. Mokrik, Regional regularities of radiocarbon distribution in groundwaters of the Baltic artesian basin, Water Resour. 6, 243-248 (1979) [in Russian].

[31]J. Pärn, S. Affolter, J. Ivask, S. Johnson, K. Kirsimäe, M. Leuenberger, T. Martma, V. Raidla, S. Schloemer, H. Sepp, R. Vaikmäe, and K. Walraevens, Redox zonation and organic matter 
oxidation in palaeogroundwater of glacial origin from the Baltic Artesian Basin, Chem. Geol. 488, 149-161 (2018), https://doi.org/10.1016/j. chemgeo.2018.04.027

[32]V. Raidla, K. Kirsimäe, R. Vaikmäe, E. Kaup, and T. Martma, Carbon isotope systematics of the Cambrian-Vendian aquifer system in the northern Baltic Basin: Implications to the age and evolution of groundwater, Appl. Geochem. 27, 2042-2052 (2012), https://doi.org/10.1016/j. apgeochem.2012.06.005

[33]A. Sterckx, J.M. Lemieux, and R. Vaikmäe, Representing glaciations and subglacial processes in hydrogeological models: A numerical investigation, Geofluids 2017, 1-12 (2017), https://doi. org/10.1155/2017/4598902

[34]A. Sterckx, J.-M. Lemieux, and R. Vaikmäe, Assessment of paleo-recharge under the Fennoscandian Ice Sheet and its impact on regional groundwater flow in the northern Baltic Artesian Basin using a numerical model, Hydrogeol.
J. 26, 2793-2810 (2018), https://doi.org/10.1007/ s10040-018-1838-7

[35] A. Babre, A. Kalvāns, K. Popovs, I. Retiķe, A. Dēliņa, R. Vaikmäe, and T. Martma, Pleistocene age paleo-groundwater inferred from water-stable isotope values in the central part of the Baltic Artesian Basin, Isot. Environ. Health Stud. 52, 706-725 (2016), https://doi.org/10.1080/1025601 6.2016 .1168411

[36]A. Delina, A. Kalvans, T. Saks, U. Bethers, and V. Valdis, Highlights of Groundwater Research in the Baltic Artesian Basin (University of Latvia, Riga, 2012).

[37]R. Vaikmäe, L. Vallner, H.H. Loosli, P.C. Blaser, and M. Juillard-Tardent, in: Palaeowaters in Coastal Europe: Evolution of Groundwater Since the Late Pleistocene, Special Publications, eds. W.M. Edmunds, C.J. Milne, Vol. 189 (Geological Society, London, 2001) pp. 17-27, https://doi.org/10.1144/GSL.SP.2001.189.01.03

\title{
GILIŲJŲ VANDENINGŲ SLUOKSNIŲ POŽEMINIO VANDENS IZOTOPINIAI IR INERTINIŲ DUJŲ AMŽIAI SU TĖKMĖS MODELIAVIMU BALTIJOS ARTEZINIAME BASEINE
}

\author{
R. Mokrik, V. Samalavičius, M. Gregorauskas, M. Bujanauskas
}

Vilniaus universiteto Geomokslu institutas, Vilnius, Lietuva

\begin{abstract}
Santrauka
Tyrime buvo palygintas modeliuotas požeminio vandens srauto judèjimo laikas vidutiniuose ir giliuose vandeninguose sluoksniuose su ${ }^{4} \mathrm{He}$ ir ${ }^{81} \mathrm{Kr}$ izotopais nustatytu amžiumi Baltijos artezinio baseino (BAB) požeminiame vandenyje. Izotopiniai ir hidrogeocheminiai duomenys padejo kalibruoti ir patikrinti anksčiau sukurtus nuostovios filtracijos 3D požeminio vandens srauto modelius. Padidejęs helio kiekis vandeninguose sluoksniuose sutampa su kristalinio pamato ir nuosédinès dangos lūžių zonomis, esančiomis šalia rapakivio granito masyvų Baltijos jūros pakrantèje. Atmosferinès
\end{abstract}

kilmès ${ }^{81} \mathrm{Kr}$ izotopo trajektorija turètu atitikti modeliuotą dalelių judèjimo kryptị ir parodyti panašius požeminio vandens amžiaus rezultatus. Gauti duomenys atskleidé, $\mathrm{kad}{ }^{81} \mathrm{Kr}$ izotopo ir modeliuotų dalelių amžiai reikšmingai skiriasi. Skaitmeniniame modelyje trūksta vidinių geologinių struktūrinių elementų, tokių kaip lūžių zonos, todèl norint atspindèti natūralias sąlygas būtina koreguoti hidraulinius modelio parametrus. Remiantis izotopiniais ir hidrogeocheminiais duomenimis, patvirtinta $\mathrm{BAB}$ vandens helio anomalijų kilmé, formavimosi procesai ir amžius. 